\title{
SPATIAL DISTRIBUTION AND STRUCTURAL VARIATION OF Copaifera arenicola IN A CAATINGA FRAGMENT
}

\author{
Dráuzio Correia Gama ${ }^{1 *}$, Robério Anastácio Ferreira ${ }^{2}$, Janisson Batista de Jesus ${ }^{3}$, \\ José Monteiro do Nascimento Júnior ${ }^{4}$ \\ ${ }^{1}$ Bahia Southwest State University - UESB, Vitória da Conquista, Bahia, Brazil - drauziogama @ hotmail.com \\ ${ }^{2}$ Federal University of Sergipe - UFS, Forest Sciences Department - DCF, São Cristóvão, Sergipe, Brazil \\ ${ }^{3}$ Federal University of Rio Grande do Sul - UFRGS, Porto Alegre, Rio Grande do Sul, Brazil \\ ${ }^{4}$ Bahia State University - UNEB, Paulo Afonso, Bahia, Brazil
}

Received for publication on: 23/03/2019 - Accepted for publication on: 03/06/2019

\begin{abstract}
Resumo
Distribuição espacial e variação estrutural de Copaifera arenicola em um fragmento de Caatinga. O estudo da distribuição espacial de populações arbóreas tem sido importante por revelar como os indivíduos se encontram organizado horizontalmente no ambiente facilitando o entendimento estrutural e as formas de colonização e dispersão de propágulos. Objetivou-se neste trabalho estudar o padrão de distribuição espacial da espécie arbórea Copaifera arenicola [(Ducke) J. Costa e L.P.Queiroz] e sua relação estrutural com o perfil altimétrico em um fragmento de Caatinga no município de Ribeira do Pombal, Bahia. Foi realizado o censo de todos os indivíduos da área com circunferência à altura do peito $(\mathrm{CAP}) \geq 6 \mathrm{~cm}$. A análise da distribuição espacial foi feita para toda a população usando-se a função univariada $K$ de Ripley, com raio máximo de busca (h) de $128 \mathrm{~m}$. Foram encontrados 409 indivíduos, correspondendo a uma densidade absoluta de 89,49 ind. ha ${ }^{-1}$ e $0,681 \mathrm{~m}^{2} \cdot \mathrm{ha}^{-1}$ de área basal. O conjunto de indivíduos de $C$. arenicola corresponde a uma população estável e em fase de expansão, apresentando um maior número de indivíduos jovens e médios. O padrão de distribuição espacial dos indivíduos na área de estudo foi o arranjo uniforme. Nenhuma das classes altimétricas da área apresentou influencia diferenciada à estrutura e à distribuição dos indivíduos arbóreos.
\end{abstract}

Palavras-chave: Regeneração natural; semiárido; copaiba; miroró; pau-preto.

\begin{abstract}
The study of spatial distribution of tree populations has proven to be important for revealing how individuals are horizontally organized in the environment, facilitating the structural understanding and forms of colonization and dispersion of propagules. The present work aimed at studying the pattern of spatial distribution of tree species Copaifera arenicola [(Ducke) J. Costa e L.P.Queiroz] and its structural relation with the altimetric profile in a Caatinga fragment in Ribeira do Pombal municipality, Bahia. Census of all individuals in the area with circumference at breast height $(\mathrm{CBH}) \geq 6 \mathrm{~cm}$ was performed. The spatial distribution analysis was conducted for the whole population using Ripley K univariate function, with maximum search radius (h) of $128 \mathrm{~m} .409$ individuals were found, corresponding to absolute density of 89.49 ind. ha ${ }^{-1}$ and $0.681 \mathrm{~m}^{2}$. ha $\mathrm{h}^{-1}$ of basal area. The group of $C$. arenicola individuals corresponds to a stable population in expansion phase, presenting higher number of young and medium individuals. The pattern of spatial distribution of individuals in the area under study was the uniform arrangement. None of the altimetric classes of the area had a different influence on the structure and distribution of arboreal individuals.

Keywords: Natural regeneration; semiarid; copaíba; miroró; pau-preto.
\end{abstract}

\section{INTRODUCTION}

Among the species of Copaifera L. genus (belonging to botanical family Fabaceae), 17 of them, existing in Brazil, are considered extra-Amazon, as is the case of Copaifera arenicola [(Ducke) J. Costa e L. P. Queiroz] (COSTA; QUEIROZ, 2010). This species is endemic in Caatinga Phytogeographic Domain sedimentary region and is exclusively distributed across Bahia, Ceará, Pernambuco and Rio Grande do Norte states. In Bahia it occurs in Raso da Catarina Ecoregion, in sandy and deep soils (GAMA; NASCIMENTO JÚNIOR, 2019).

In Ribeira do Pombal municipality (BA), the species is commonly known as miroró or pau-preto, and its wood was explored for a long time for energy production in the municipality through indiscriminate cut, causing reduction in its natural stock to few populations (GAMA; NASCIMENTO JÚNIOR, 2019). It is known that indiscriminate timber exploration may compromise both the horizontal and vertical structure, like abundance and recruitment of new individuals of the species, increasingly affecting the population resilience capacity and weakening the species (ROCHA et al., 2013). 
In these circumstances, studies associated to spatial distribution have been important for revealing the horizontal organization of individuals in the environment of a given species, one of the main requirements to understand the dynamics of plant populations, facilitating the structural understanding and propagules' colonization and dispersion processes (NEGRINI et al., 2012; SANTANA et al., 2016). This information can assist with more details in forms of interventions at forestry and management levels, where applicable.

The species spatial distribution can also be understood as the result of the influence of a dynamics of ecological processes that, combined with biotic and abiotic factors, form different types of spatial patterns (COSTA et al., 2011; SANTANA et al., 2016), like the random pattern, the one considered when the distribution of individuals in the space occurs independently in any place of the area, and randomically, in such a way that any individual has equal chances of independently occurring in any location of the area; the aggregate pattern, characterized by the proximity of individuals, tending to occur in groups, with more chances for the individual to influence the presence of the other; or uniform pattern, distributed with regular intervals inside the population, equally spaced from each other, occurring in a way that will avoid the proximity of the other, interfering with the reproductive biology and trophic structure (NEGRINI et al., 2012; PICCOLI et al., 2014).

In this aspect, structural changes are outstanding in the canopy, varying the angles of penetration, distributions and incidence of light in the forest interior; relief, causing different soil substrate conditions to microenvironments formed by micro-topographic variations that determine occurrence of microorganisms, germination, establishment and mortality of seedlings; also generating diversities of micro-climates per altimetric profile, according to the type of soil, humidity regimes, geological formation and altitude, as well as countless factors directly and indirectly associated to distribution patterns, in addition to secondary dispersions involved (NEGRINI et al., 2012; KITAGAWA et al., 2014; MARCHESAN et al., 2016).

With this regard, the influence of the relief is observed as key factor of the tropical forest structure and composition at the level of soil surface declivity, subject to variable environmental situations between top and base; drier high areas and more humid low areas; and transportation of soil particles, causing processes of nutrients' cycling and restricting local conditions within which trees grow, which is fundamental to explain landscape heterogeneity (KITAGAWA et al., 2014; JUCKER et al., 2018).

For that matter, topography in local scale is an important element to be considered in studies on forests' spatial distribution and structure, correlating environmental variables and distribution of individuals.

Thus, the present work aimed at studying the pattern of spatial distribution of Copaifera arenicola and its structural relation with the altimetric profile in a Caatinga fragment in Ribeira do Pombal municipality, (BA), in order to subsidize sustainable management practices and species conservation strategies in the region, considering the hypothesis that the population of Copaifera arenicola presents spatial distribution that is indifferent to topographic variation.

\section{MATERIAL AND METHODS}

\section{Characterization of the area of study}

The study was conducted from August 2016 to February 2017, in a 4.57 ha area of deep red-yellow latosol in quartz-sand of sedimentary origin, located in Bahia Northeast mesoregion (GAMA; JESUS, 2018), with UTM coordinates 24 South: $X=548057$ and $Y=8799206 ; X=548224$ and $Y=8799399$, Datum SIRGAS 2000, and image acquired from Landsat-8 satellite - USGS/2016, in Ribeira do Pombal municipality, Bahia, whose territorial extension of $762.212 \mathrm{~km}^{2}$ (GAMA; JESUS, 2018).

Included in Raso da Catarina ecoregion, of Caatinga Phytogeographic Domain, Ribeira do Pombal is constituted of hipoxerophilic vegetation called sedimentary dry forest, with average rainfall and temperature of $700 \mathrm{~mm}$.year ${ }^{-1}$ and $24.2^{\circ} \mathrm{C}$.year ${ }^{-1}$, respectively (GAMA; JESUS, 2018). The municipality climate is characterized as warm and dry, Bsh type, according to Köppen climate classification.

\section{Data obtention}

A prospection inventory (census) of the area was made considering as inclusion factor all individuals with $\mathrm{CBH}$ (circumference at breast height) $\geq 6 \mathrm{~cm}$, according to protocol of measurements for Caatinga from Caatinga Forest Management Network - RMFC/2005. The total height of trees was measured using a telescopic dendrometric stick and stem $\mathrm{CBH}$ at $1.30 \mathrm{~m}$ above soil level with a measuring tape graduated in $\mathrm{cm}$. All individuals from the $C$. arenicola population were georeferenced in UTM coordinates using a GPS (Global Positioning System) device. 


\section{Data analysis}

For the vertical structure analysis, lower, medium and upper strata of heights were used based on the prevailing height where the distribution of the number of trees occurred by height classes defined as follows: Lower Stratum: $\mathrm{h}<1 / 3 *$ hdom; Medium Stratum: $1 / 3 *$ hdom $\leq \mathrm{h}<\mathrm{hdom} * 2 / 3$ and Upper Stratum: $\mathrm{h} \geq \mathrm{hdom} * 2 / 3$ (LAMPRECHT, 1990).

For the horizontal structure analysis diameter distribution was considered through the center of diameter classes, with eight classes and $5 \mathrm{~cm}$ class interval. Distribution of individuals per altimetric class across the different altimetric profiles was also performed.

Spatial distribution analysis was conducted for the whole population using Ripley K univariate function, with R® language software, version 2.0.1 (IHAKA; GENTLEMAN, 1997), estimated by Splancs package (ROWLINGSON; DIGGLE, 2004). Maximum search radius (h) of $128 \mathrm{~m}$ was considered for being the approximate half of the largest longitudinal axis of the area under study, with significance of the distribution deviations $\mathrm{L}(\mathrm{h})$ determined from the construction of an envelope of full independence among individuals, calculated with 500 simulations, which are presented in the $\mathrm{K}(\mathrm{h})$ function diagram.

For the study of structural variation of Copaifera arenicola individuals distributed per altimetric class in the area, class correlations analysis was performed using the correlation matrix and considering the following variables: number of individuals, height strata and basal area of trees, using Pearson correlation coefficient ( $\mathrm{p}<0.05)$ in ActionStat ${ }^{\circledR}$ software, version 3.3.2.

Thematic maps of distribution and altimetry were produced with QuantumGis ${ }^{\circledR}$ software version 3.6.0 for all individuals, using their geographic coordinates, where they were interpolated by the IDW (Inverse Distance Weighting) method for presenting better spatial distribution of values, with Spatial Analyst tool.

\section{RESULTS}

The study analyzed 409 Copaifera arenicola individuals, corresponding to absolute density of 89.49 ind. $\mathrm{ha}^{-1}, 37.65 \%$ (154) of them distributed in the medium stratum, 33.25\% (136) in upper stratum and 29.09\% (119) in lower stratum (Figure 1).

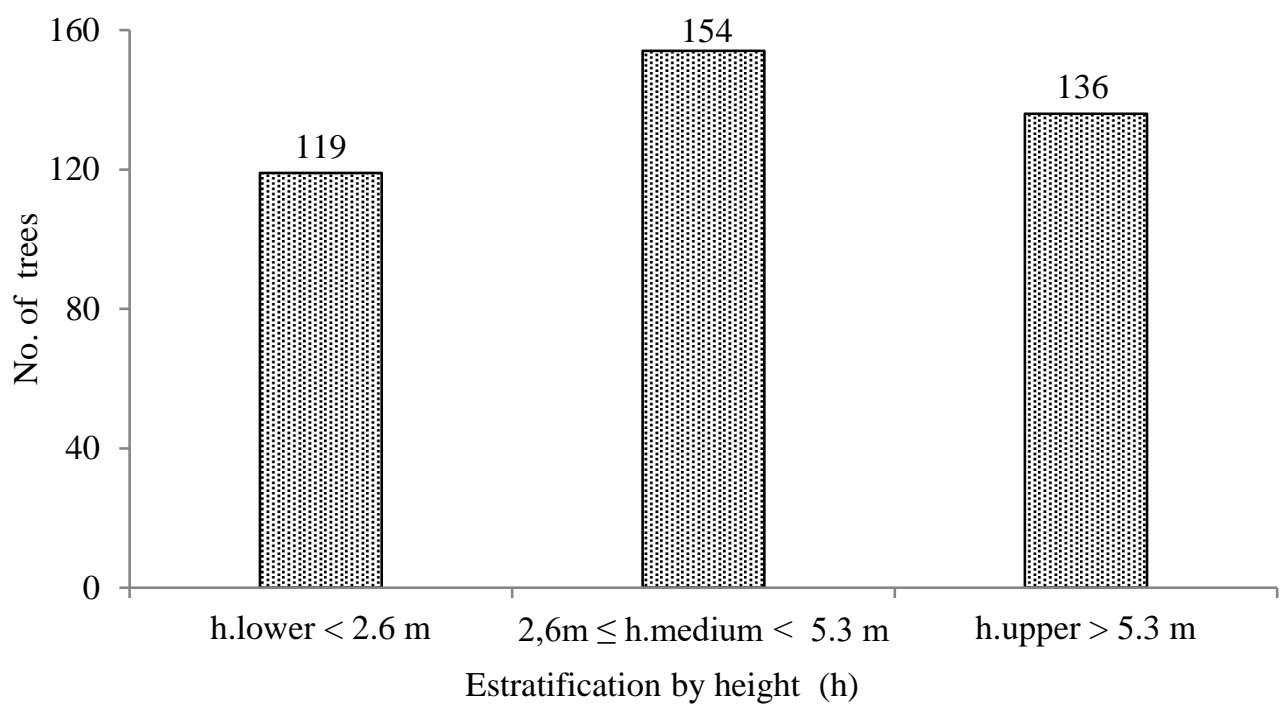

Figure 1. Distribution in height per stratum (upper, medium and lower) of a population of Copaifera 1662renicola in Caatinga area, in Ribeira do Pombal municipality, Bahia.

Figura 1. Distribuição em altura por estrato (superior, médio e inferior) de uma população de Copaifera arenicola em área de Caatinga, no município de Ribeira do Pombal, Bahia. 
The diameter distribution of C. arenicola individuals presented frequency curve as an inverted J, relative to an extremely asymmetric distribution, with maximum ordinate point at the left end, showing expressive domain of young or thin individuals concentrated in the first class, which corresponds to practically half of the whole population $(49.87 \%)$, followed by the second class, with $26.16 \%$ of individuals with class center of $8.7 \mathrm{~cm}$ (Figure 2).

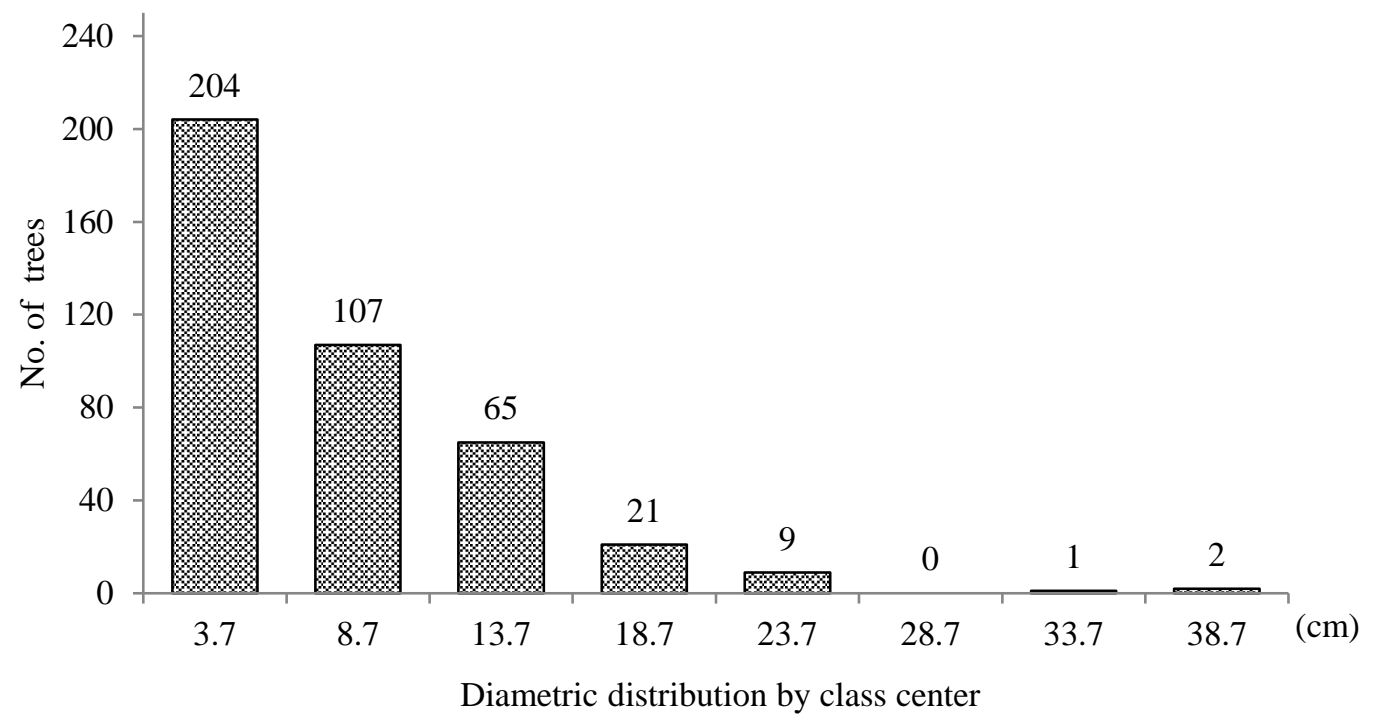

Where: $3.7 \mathrm{~cm}$ corresponds to the diameter class center between $1.9-5.5 \mathrm{~cm} ; 8.7 \mathrm{~cm}(5.5-11.8 \mathrm{~cm}) ; 13.7 \mathrm{~cm}(11.8-15.16 \mathrm{~cm}) ; 18.7 \mathrm{~cm}(15.16$ $-21.7 \mathrm{~cm}) ; 23.7 \mathrm{~cm}(21.7-25.6 \mathrm{~cm}) ; 28.7 \mathrm{~cm}(25.6-31.7 \mathrm{~cm}) ; 33.7 \mathrm{~cm}(31.7-35.7 \mathrm{~cm})$ and $38.7 \mathrm{~cm}$ corresponds to the diameter class center between $35.7-41.7 \mathrm{~cm}$.

Figure 2. Diameter distribution per class center of a population of Copaifera arenicola in Caatinga area of Ribeira do Pombal municipality, Bahia.

Figura 2. Distribuição diamétrica por centro de classes de uma população de Copaifera arenicola em uma área de Caatinga, no município de Ribeira do Pombal, Bahia.

It was also observed that, among vertical and horizontal structure, the highest number of individuals, $76 \%$, is concentrated in the two first diameter classes $(<8.7 \mathrm{~cm})$, and they are distributed along lower and medium heights, corresponding to $66.8 \%$ of the individuals.

With Ripley K function (Figure 3a) of UTM projected geographic coordinates (Figure 3c), it was verified that the pattern of spatial distribution of Copaifera arenicola population tended to uniform arrangement in all the different scales, which is explained by the $\mathrm{K}(\mathrm{h})$ function straight located below the upper and lower limits of the intervals.

It was also observed that the disposition of the altimetric level is due to the relatively rough area, distributed across five altimetric classes with $30 \mathrm{~m}$ difference between the upper and lower portions (Figure $3 \mathrm{~b}$ ). 

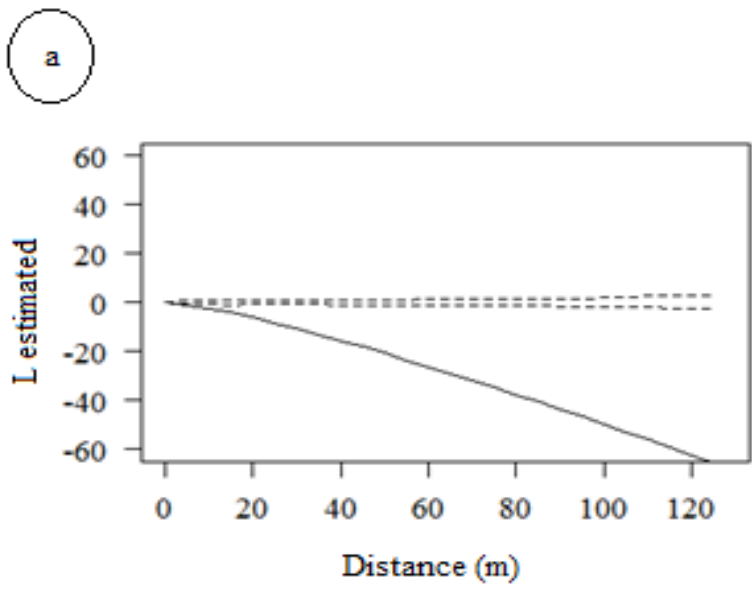
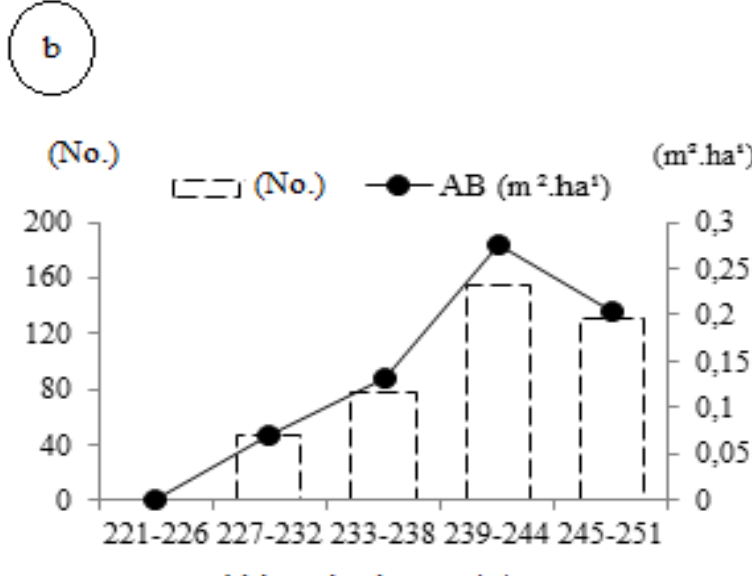

Altimetric classes (m)
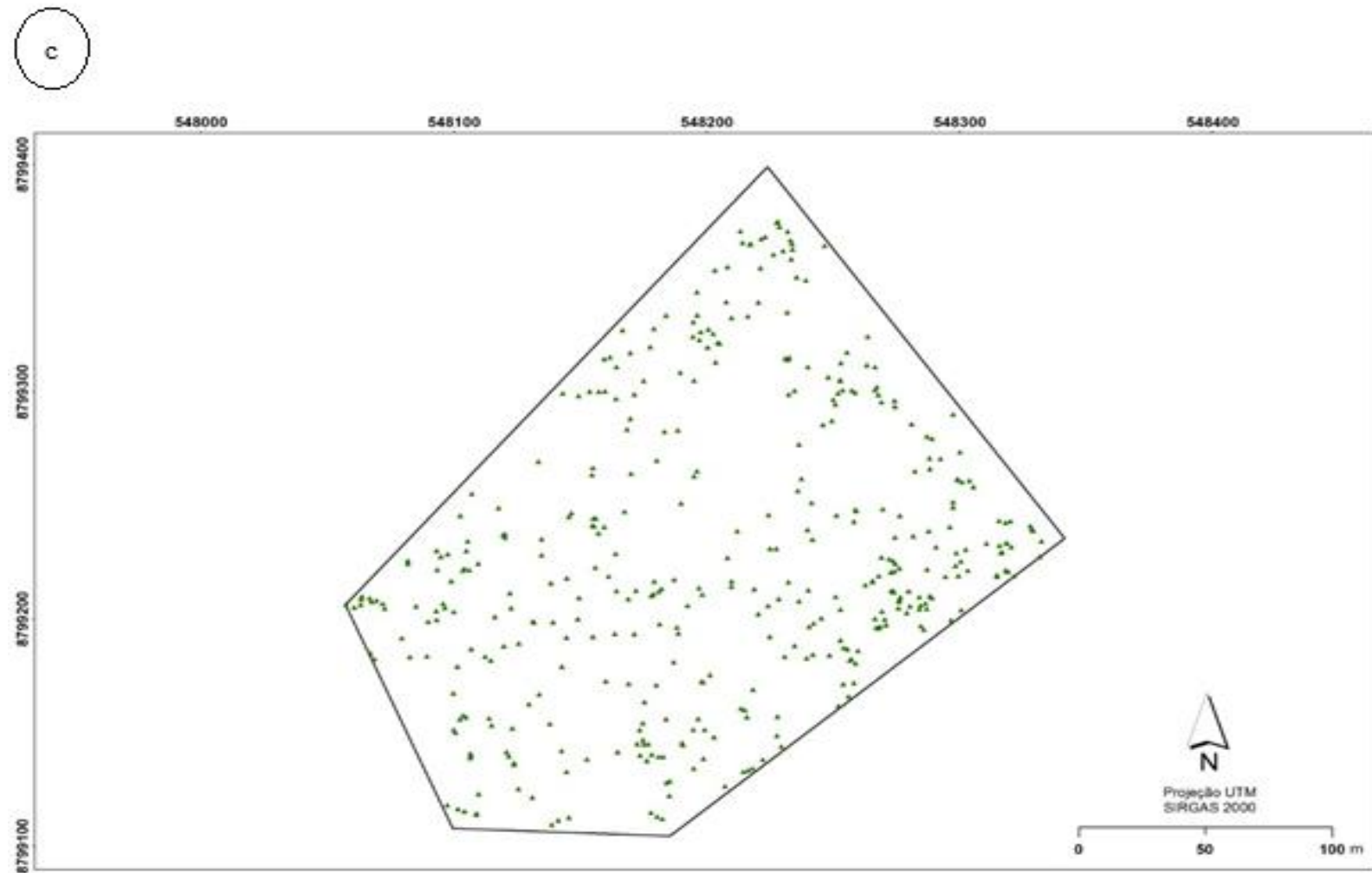

Figure 3. Uniform pattern of distribution by Ripley K Function (a); distribution per number of individuals (No.) and basal area (BS) altimetric gradient of the area (b) and spatial distribution of georeferenced individuals (c) of a population of Copaifera arenicola in Caatinga area of Ribeira do Pombal municipality, Bahia.

Figura 3. Padrão uniforme de distribuição pela Função $K$ de Ripley (a); distribuição por número de indivíduos (No.) e área basal (AB) pelo gradiente altimétrico da área (b) e distribuição espacial dos indivíduos georeferenciados (c) de uma população de Copaifera arenicola em uma área de Caatinga, no município de Ribeira do Pombal, Bahia.

With the disposition of the population of $C$. arenicola in the area altimetric gradient classes, with $30 \mathrm{~m}$ of difference, a concentration of individuals distributed in the last two classes (upper portion) was observed, corresponding to $69.68 \%$ of the population and $0.48 \mathrm{~m}^{2}$. ha- $(70.48 \%)$ of the total basal area $\left(0.681 \mathrm{~m}^{2}\right.$. ha $\left.\mathrm{h}^{-1}\right)$, as shown in Table 1. 
Table 1. Distribution per altimetric classes of the area (I, II, III, IV and V); basal area $\left(\mathrm{m}^{2}\right.$. ha $\mathrm{a}^{-1}$ ) and height (lower $=\mathrm{h}<2.6 \mathrm{~m}$; medium $=2.6 \leq \mathrm{h}<5.3 \mathrm{~m}$ and upper $=\mathrm{h}>5.3 \mathrm{~m}$ ) of Copaifera arenicola individuals, in Caatinga area of Ribeira do Pombal municipality, Bahia.

Tabela 1. Distribuição por classes altimétricas da área (I, II, III, IV e V); área basal $\left(\mathrm{m}^{2}\right.$. ha $\left.{ }^{-1}\right)$ e altura (inferior $=\mathrm{h}$ $<2,6 \mathrm{~m}$; médio $=2,6 \leq \mathrm{h}<5,3 \mathrm{~m}$ e superior $=\mathrm{h}>5,3 \mathrm{~m}$ ) de indivíduos de Copaifera arenicola, em uma área de Caatinga, no município de Ribeira do Pombal, Bahia.

\begin{tabular}{|c|c|c|c|c|c|}
\hline \multirow{2}{*}{$\begin{array}{l}\text { Altimetric } \\
\text { classes (m) }\end{array}$} & \multirow{2}{*}{$\begin{array}{l}\text { No. of } \\
\text { tress }\end{array}$} & \multirow{2}{*}{$\begin{array}{c}\text { Basal area } \\
\left(\mathrm{m}^{2} \cdot \mathrm{ha}^{-1}\right)\end{array}$} & \multicolumn{3}{|c|}{ Stratified height distribution $(\mathrm{h})$} \\
\hline & & & Lower & Medium & Upper \\
\hline (I) $221-226$ & 000 & 0.000 & (00) $00.0 \%$ & (00) $00.0 \%$ & (00) $00.0 \%$ \\
\hline (II) 227 - 232 & 047 & 0.070 & (18) $38.3 \%$ & (13) $27.7 \%$ & (16) $34.0 \%$ \\
\hline (III) $233-238$ & 077 & 0.131 & (28) $36.4 \%$ & (21) $27.3 \%$ & (28) $36.4 \%$ \\
\hline (IV) 239 - 244 & 155 & 0.276 & (36) $23.2 \%$ & (67) $43.2 \%$ & (52) $33.5 \%$ \\
\hline (V) $245-251$ & 130 & 0.204 & (37) $28.5 \%$ & (53) $40.8 \%$ & (40) $30.8 \%$ \\
\hline
\end{tabular}

Classes II and III accounted for the smallest number of individuals represented, in the vast majority, by individuals from the lower stratum (probably younger individuals), respectively $38.3 \%$ and $36.4 \%$. Class III is still superior to the others in number of individuals from the upper stratum (36.4\%). The altimetric classes IV and V, in turn, concentrated the largest number of individuals in the population with predominance in the average height stratum, $43.2 \%$ and $40.8 \%$, respectively, in addition to higher values of basal areas. And the Class I did not present data because it is a small extension located at the beginning of the area.

It can be seen in Figure 4 that both results were considered significant $(\mathrm{p}<0.05)$ and demonstrate that all coefficients have strong correlations $(0.9-1.0)$ in the altimetric classes by analyzing the Pearson correlation matrix, with the exception of Class I, as it corresponds to a small area without individuals.

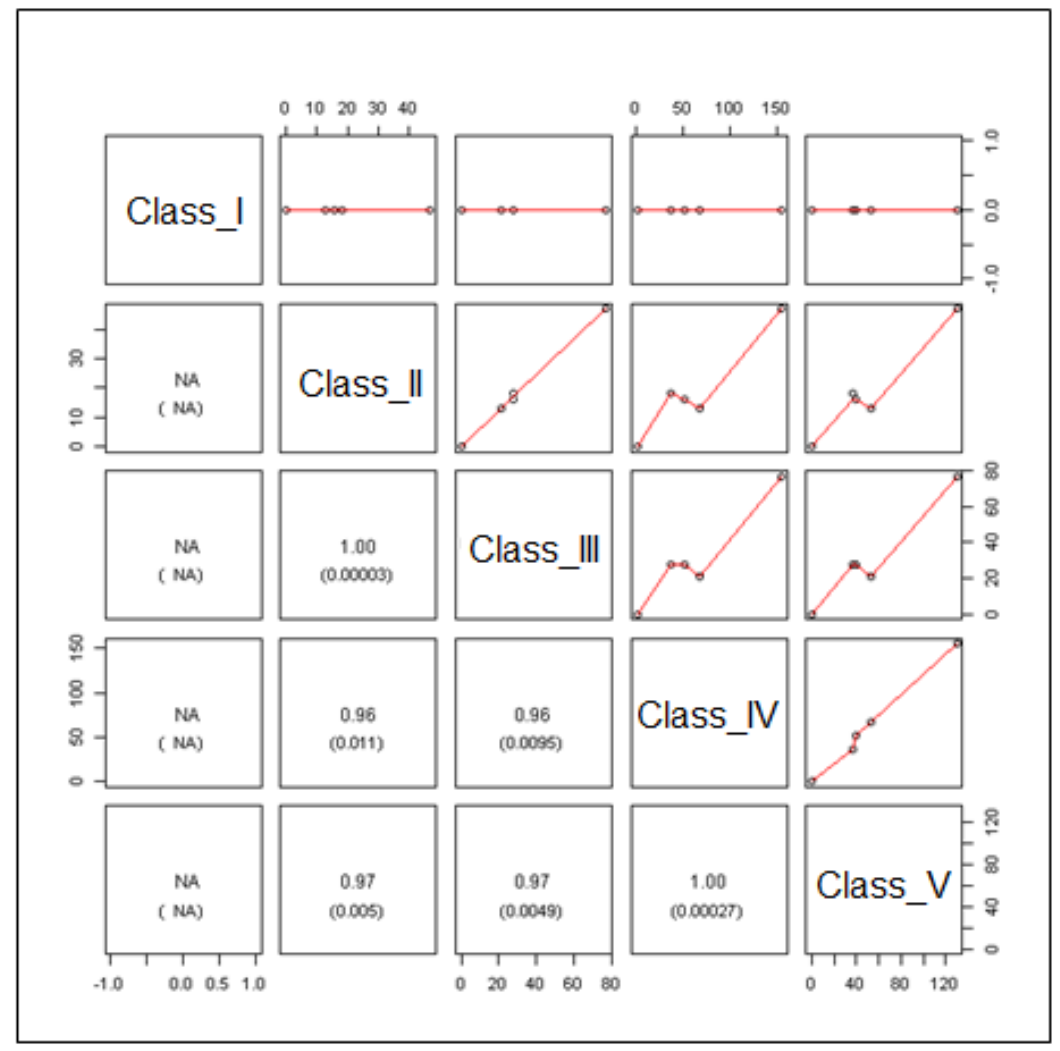

Figure 4. Pearson's correlation $(\mathrm{p}<0.05)$ of the altimetric classes of the area and spatial distribution of the individuals of Copaifera arenicola individuals, in Caatinga area of Ribeira do Pombal municipality, Bahia.

Figura 4. Correlação de Pearson $(\mathrm{p}<0,05)$ das classes altimétricas da área e distribuição espacial dos indivíduos de Copaifera arenicola em uma área de Caatinga, no município de Ribeira do Pombal, Bahia.

FLORESTA, Curitiba, PR, v. 50, n. 3, p. 1660 - 1668, jul/set 2020

Gama, D. C. et.al.

ISSN eletrônico 1982-4688 


\section{DISCUSSION}

Given the vertical and horizontal structure of Copaifera arenicola population, it is probably a stable population in its natural regeneration and expansion phase, since, according to Lehn (2007), the higher number of individuals are concentrated in classes with lower average height. And the J-shape distribution curve observed in the study represents, according to Luken (1990), a population with balance between death and recruitment, which may have occurred in the area, possibly as response to some sort of disturbance, for example.

In a study on the distribution of Bauhinia cheilantha ((Bong.) Steud) in two Caatinga fragments in Sergipe, Silva e Oliveira (2015), observed a similar stability behavior under anthropic interference, though one of them in initial phase of regeneration and the other a more advanced stage. The same phenomenon was observed in a study by Alves Júnior et al. (2013) in Caatinga area of Floresta municipality (PE), where an advanced stage of regeneration was found in individuals concentrated in medium $(39.23 \%)$ and upper $(38.27 \%)$ heights.

So, it is understood that anthropic disturbance has been a recurrent factor in Caatinga remainings, affecting vegetation development to its climax state, concentrating stable populations with individuals in the lowest height and diameter classes, as observed in the population of Copaifera arenicola.

With regard to the uniform spatial distribution pattern found, it is due, probably, among other possible factors, to the action of secondary dispersing agents like ants, for forming nets in general distributed regularly in the ecosystems, at the expense of dispersion by wind, which normally results in random dispersion, since Copaifera arenicola fruits don't have floating structures and are heavy and dry, which could cause aggregate spatial distribution, according to Negrini et al. (2012).

Moreover, the uniform distribution pattern of Copaifera arenicola makes it less susceptible to competition and seed predation factors, offering to larger species higher chances of recruitment of new individuals, according to Deminicis et al. (2009), and can provide more probability of survival of seedlings, since for Capretz et al. (2012), the tendency of higher competition occurs among aggregated trees, chiefly among young individuals, with higher level of aggregation by recruitment, therefore tending to suffer higher mortality rates by selecting the species in the habitat.

As to the population disposition per altimetric classes of the area, it is observed that the uniform spatial distribution of individuals occurs across all the five altimetric classes in their different gradients. Córdula et al. (2010) remark that the distribution of a species can also be more related to the substrate associated to local climate conditions than to its geographic position. For Holanda et al. (2015), one of the factors is the distribution of humidity in the soil, where water stress becomes more limiting in geographic distribution.

On the other hand, it is worth observing that class IV is superior to all classes in number of individuals and basal area, and class III presents superior number of individuals in lower and upper strata than the other classes, which could probably be explained by the fact that there are better environmental conditions, since for Rodrigues et al. (1989) fertility in soils reduces with increase in altitude across the gradient.

It was also observed that, due to the balance of number of individuals with lower and upper height colonizing the lowest areas and individuals in medium stratum in upper classes, one can suppose that there is no topographic influence in the distribution of $C$. arenicola in the area studied. For that matter, Rodrigues et al. (1989) observe that some characteristics of the environment, such as luminosity and water in the soil probably act jointly with relief, conditioning different micro-environments, and compensating them.

In a similar study, in area with altimetric difference of $33.14 \mathrm{~m}$ in Uberlândia-MG region, Cardoso e Schiavini (2002) observed different conditions in the distribution of 20 species across three areas. In gallery forests, with varied soil moistures, the more abundant species were in the intermediate portion and the lowest number of individuals was observed in the low portion, due to water excess during floods. In the region of semi-deciduous forest, species were favored by optimal luminosity conditions of edges and clearings, while in Cerradões, under uniform soil substrate conditions, the phyto-physiognomy present did not suffer topographic influence in the species distribution.

The index obtained in the correlation matrix analysis $(0.9-1.0)$ indicates strong correlation for all altimetric classes to the number of individuals, height strata and basal area, thus showing that there is no characteristic in the area that would benefit or harm a given altimetric class in terms of concentration of individuals (or lack of concentration) in the whole area of study, providing equal conditions to the population in all altimetric classes. Since dependence of a certain variable assessed is important to characterize tree population in its allocation across the area, it shows to be common for all trees per each class.

Though topographic characteristics are clearly important in forest landscapes, Jucker et al. (2018) indicate that the force, form and complexity of relations are specific, at least partially, of the place. As to humidity, for example, Koirala et al. (2017) remark that opposite interactions of vegetation with soil moisture are more associated to differences in the vegetation than to climate and surface characteristics.

FLORESTA, Curitiba, PR, v. 50, n. 3, p. 1660 - 1668, jul/set 2020

Gama, D. C. et.al.

ISSN eletrônico 1982-4688

DOI: $10.5380 /$ rf.v50 i3. 65583 
That can explain $C$. arenicola species behavior in the area of study, where the altimetric gradient studied indicates that it is probably an area with equal conditions for the species establishment in its spatial distribution, in all the different altimetric positions of the area. Moreover, possible variations in soil substrates or water conditions in the area, locally, make it impossible to concentrate individuals in a given altimetric position at the expense of another in the species spatial distribution.

\section{CONCLUSIONS}

- According to the structural patterns considered, the set of individuals of Copaifera arenicola corresponds to a stable population in its natural regeneration and expansion phase, presenting higher number of young and medium individuals.

- The spatial distribution pattern found for Copaifera arenicola population was the uniform arrangement in all possible scales of confidence intervals.

- The five different altimetric classes found in the area have equal influence in the distribution of Copaifera arenicola individuals, since the correlation of variables number of individuals, strata and basal area revealed strong coefficient $(0.9-1.0)$ in all classes.

\section{REFERENCES}

ALVES JÚNIOR, F. T.; FERREIRA, R. L. C.; SILVA, J. A. A. D.; MARANGON, L. C.; CESPEDES, G. H. G. Natural regeneration of an area of caatinga vegetation in Pernambuco state, northeastern Brazil. Cerne, Lavras, v. 19, n. 2, p. 229-235, 2013.

CAPRETZ, R. L.; BATISTA, J. L. F.; SOTOMAYOR, J. F. M.; CUNHA, C. R. da.; NICOLETTI, M. F.; RODRIGUES, R. R. Padrão espacial de quatro formações florestais do estado de São Paulo, através da função K de Ripley. Ciência Florestal, Santa Maria, v. 22, n. 3, p. 551-565, 2012.

CARDOSO, E.; SCHIAVINI, I. Relação entre distribuição de espécies arbóreas e topografia em um gradiente florestal na Estação Ecológica do Panga (Uberlândia, MG), Revista Brasileira de Botânica, São Paulo, v. 25, n. 3, p. 277-289, 2002.

CÓRDULA, E.; QUEIROZ, L. P. de.; ALVES, M. Diversidade e distribuição de Leguminosae em uma área prioritária para a conservação da Caatinga em Pernambuco-Brasil. Revista Caatinga, Mossoró, v. 23, n. 3, p. 3340, 2010.

COSTA, J. A. S; QUEIROZ, L. P. D. Lectotypifications and nomenclatural notes in Copaifera L.(LeguminosaeCaesalpinioideae-Detarieae). Kew Bulletin, Londres, v. 65, n. 3, p. 475-478, 2010.

COSTA, R. C. D.; SANTOS, F. A. M. D. Padrões espaciais de Qualea grandiflora Mart. em fragmentos de cerrado no estado de São Paulo. Acta Botanica Brasilica, Belo Horizonte, v. 25, n. 1, p. 215-222. 2011.

DEMINICIS, B. B.; VIEIRA, H. D.; ARAÚJO, S. A. C.; JARDIM, J. G.; PÁDUA, F. T.; CHAMBELA, N. A. Dispersão natural de sementes: importância, classificação e sua dinâmica nas pastagens tropicais. Archivos de Zootecnia, Córdoba, v. 58, p. 35-58, 2009.

GAMA, D. C.; JESUS, J. B. de. Aspecto geomorfológico, hidroclimático e ambiental da microrregião de Ribeira do Pombal, Bahia, Brasil. Geoambiente, Itajaí, n. 32, p. 57-73, 2018.

GAMA, D. C.; NASCIMENTO JÚNIOR, J. M. Copaifera Arenicola (Ducke) J. Costa \& L. P. Queiroz (Caesalpinioideae-fabaceae), em regiões do nordeste da Bahia. Agroforestalis News, Aracaju, v. 4, n. 1, p. i-viii, 2019.

HOLANDA, A. C. D.; LIMA, F. T. D.; SILVA, B. M.; DOURADO, R. G.; ALVES, A. R. Estrutura da vegetação em remanescentes de caatinga com diferentes históricos de perturbação em Cajazeirinhas (PB). Revista Caatinga, Mossoró, v. 28, n. 4, p. 142-150, 2015.

IHAKA, R; GENTLEMAN, R. The R Project for Statistical Computing, Bell Laboratories. Nova Jersey, United States of America - USA, 1997. Disponível em: <https://www.r-project.org/>. Acesso em: 18 mar. 2017.

JUCKER, T., BONGALOV, B., BURSLEM, D. F., NILUS, R., DALPONTE, M., LEWIS, S. L.; PHILLIPS, O. L.; QIE, L.; COOMES, D. A. Topography shapes the structure, composition and function of tropical forest landscapes. Ecology letters, Oxford, v. 21, n. 7, p. 989-1000, 2018. 
KITAGAWA, R.; KONDO, H.; SAKAI, A. Spatial pattern of forest structure mediated by topography in a steep mountain basin in West Tanzawa, Japan. Journal of forest research, v. 19. n. 1, p. 205-214, 2015.

KOIRALA, S.; JUNG, M.; REICHSTEIN, M.; DE GRAAF, I. E.; CAMPS-VALLS, G.; ICHII, K.; PARPALE, D.; RÁDULY, B.; SCHWALM, C. R.; TRAMONTANA, G.; CARVALHAIS, N. Global distribution of groundwater-vegetation spatial covariation. Geophysical Research Letters, Baltimore, v. 44, n. 9, p. 4134-4142, 2017.

LAMPRECHT, H. Silvicultura nos trópicos: ecossistemas florestais e respectivas espécies arbóreas. Possibilidades e métodos de aproveitamento sustentado. Eschborn: Deustsche Gessells chaft für technisch Zusammenarbeti (GTZ) GmbH, 1990. 343 p.

LEHN, C. R. Estrutura populacional e padrão de distribuição espacial de Cyathea delgadii Sternb. (Cyatheaceae) em uma Floresta Estacional Semidecidual no Brasil Central. Revista Biociências, Porto Alegre, v. 13, n. 3-4, p. 188-195, 2007.

LUKEN, J. O. Directing ecological succession. New York: Chapman and Hall, 1990. 251 p.

MARCHESAN, J.; PEDRALI, L. D.; TRAMONTINA, J.; ALBA, E.; MELLO, E. P.; PEREIRA, R. S. Análise da relação entre a evolução florestal e a declividade utilizando imagens Landsat. Nativa, Sinop, v. 4, n. 1, p. 5357, 2016.

NEGRINI, M.; AGUIAR, M. de. D.; VIEIRA, C. T.; SILVA, A. C. da.; HIGUCHI, P. Dispersão, distribuição espacial e estratificação vertical da comunidade arbórea em um fragmento florestal no Planalto Catarinense. Revista Árvore, Viçosa, v. 36, n. 5, p. 919-929, 2012.

PICCOLI, M. C. A.; SOUZA-LEAL, T.; PEDROSO-DE-MORAES, C. Distribuição espacial de Sacoila lanceolata (Aubl.) Garay (Orchidaceae) em fragmento mesófilo de Pirassununga, São Paulo, Brasil. Nucleus, Ituverava, v.11, n.1, p.155-130, 2014.

ROCHA A. A.; RIBEIRO, I. B.; SOUSA, J. R. L. de.; BARROS, S. S.; SOUSA, P. de. S. Análise da estrutura vegetacional em uma área de caatinga no município de Bom Jesus, Piauí. Revista Caatinga, Mossoró, v. 26, n. 4 , p. 99-106, 2013.

RODRIGUES, R. R.; MOREllAtO, L. P. C.; JOLY, C. A.; LEITÃO FILHO, H. D. F. Estudo florístico e fitossociológico em gradiente altidudinal da mata estacional mesófila semidecídua na Serra do Japi, Jundiaí-SP. Revista Brasileira de Botânica, São Paulo, v. 12, p. 71-84, 1989.

ROWLINGSON, B; DIGGLE, P. Splancs: spatial and space-time point pattern analysis. R package version 2.01-15. 2004. Disponível em: 〈http://www.maths. lancs.ac.uk/rowlings/Splancs/>. Acesso em: 20 mar. 2017.

SANTANA, J. A. D. S.; SANTANA JÚNIOR, J. A. S.; BARRETO, W. da. S.; FERREIRA, A. T. da. S. Estrutura e distribuição espacial da vegetação da Caatinga na Estação Ecológica do Seridó, RN. Pesquisa Florestal Brasileira, Colombo, v. 36, n. 88, p. 355-361, 2016.

SILVA, A. C. D. C; OLIVEIRA, D. G. D. Population structure and spatial distribution of Bauhinia cheilantha (Bong.) Steud. in two fragments at different regeneration stages in the Caatinga, in Sergipe, Brazil. Revista Árvore, Viçosa, v. 39, n. 3, p. 431-437, 2015. 